Torbica Milica*

\title{
"SILENCE OF THE ADMINISTRATION" IN THE ADMINISTRATION PROCEDURE THAT IS BEING INSTITUTED BEFORE THE REAL ESTATE REGISTRY AND CABLE DUCT CADASTER
}

\begin{abstract}
Silence of the administration" represents the tool for the regular legal protection of the parties within the administrative procedure, whether the subject is the procedure being initiated by the parties who have a personal interest or due to the ex officio procedure. In both cases, either due to a long lasting procedure or to an untimely decision which is being rendered in relation to the terms envisaged by law from the side of the administration, significant damage is being endured. Moreover, in both cases, the inactivity of the administrative authorities has numerous aftereffects. The Real Estate Registry and Cable Duct Cadaster represent a Public Book which has data on immovable properties and rights regarding the very same necessary for rendering numerous other rights before the other state authorities and judiciary. Data referring to the Real Estate Registry and Cable Duct Cadaster represent the initial base while rendering the rights before the business banks and within the economic field, in general. Thus, cadaster data should be updated regularly, which presupposes both active and timely registration of documents in the Cadaster, whether based on the submitted documents for the purpose of the registration within the Cadaster, the very same documents to be adopted or a negative administrative act to be rendered. However, in practice, one can often encounter that this legal protection instrument of the parties cannot
\end{abstract}

*LLD, The Republic Geodetic Institute, Republic of Serbia, e-mail: milica.office1@gmail.com 
be applied, bearing in mind that non-acting in the administrative procedure which is being held before the Real Estate Registry and Cable Duct Cadaster has not always been caused by a non-compliance with the terms by the side of this administrative authority. Namely, the administrative procedure being held before the Real Estate Registry has its specific characteristics due to which this very Institute of the Administrative Law deserves a greater attention. The existence of the priority norm, i.e. the obligation of acting upon the requests of the order of their reception in the Real Estate Registry and Cable duct Cadaster, leads to the other point of view regarding the acting of the administrative authorities and decision rendering based either on the requests of the parties or based on ex officio within the terms envisaged by the Law.

Key words: silence of Administration, Cadaster, priority norm

\section{Introduction}

The problem of not solving cases within the given deadlines is present in all countries. Also, not only is it present, but it is also recognized as a significant cause of consequent risks and damages in various social and legal spheres. The consequences of the "silence" of the administration are reflected in violations of legal values, which can be of different breadth and severity, (Tomić, 2013). Thus, "silence" of the administration, i.e. passive attitude of the competent body which insults the legal regulations which regulate the duty of the body to solve a certain administrative case, regardless of what content it will give to the administrative act, (Milkov, 1998), violates equal protection of rights before the Constitution and law, violation of legal certainty as well as legality. The development of modern administration, both around the world and in our country, is based on the basic principles, standards, rules and instructions of the popularly called "good administration", (CFR EU, 2007/C303/01). The proclaimed human rights and freedom contained in all the highest legal acts of modern states are a reality, they exist and are not questioned, we are now in the phase of the need to create such legal systems and policies that would effectively protect and enforce those rights and that freedom.

Contemporary administration, viewed as the "real, open and dynamic system" and as a "social function of providing administrative (public) services", (Dimitrijević, 2005) must base its work on the law, it must be efficient and 
exercise public authority responsibly. Viewed through the prism of European standards, the procedure conducted before administrative bodies needs to be shortened, accelerated, deformalized, but not to the detriment of efficiency, legal certainty, legality and the principle of truth, (Tomić, 2013).

The rules of administrative procedure are of special importance for acquiring the citizens' rights, having in mind that by far the greatest number of their rights and freedom, guaranteed by the Constitution and international legal documents, is being acquired just through the actions of administrative authorities, (Lončar, 2016). Apart from the fact that the field of the protection of administrative law is very wide, it encompasses also a number of specificities and a handful of legal situations for whose solution, and having in mind their specifics, the existence of special administrative procedures is necessary. The rules of special administrative procedures, although unique, in any case mustn't deviate from the rules of general administrative procedure, nor should they, under the veil of its own specificity, diminish the level of the protection citizens' protection and legal practices guaranteed by the Law on General Administrative Procedure. Accordingly, with the Law on General Administrative Procedure, (Law on General Administrative Procedure, 2016) which undisputedly contains the quality of rules developed continuously for over eight decades, and for the purpose of maintaining stable legal order and law and citizens' freedom, the explicit obligation of adjustment of all special administrative procedures with the rules of the new Law, at latest within a year from the commencement of the application of the new Law, is listed.

\section{The concept, legal nature and legal modalities of "silence" of the administration in our legal system}

Although the "silence" of the administration is an impermissible behavior that depicts the improper conduct of administrative proceedings and deviations from the principle of legality, it cannot be said that it is illegal, (Dimitrijević, 2005). Namely, having in mind that such conduct of the administration is provided by positive legal norms, especially when taking into account that the valid legal norms regulate that in such cases a negative or positive administrative act is passed, "silence" of the administration can be considered as a behavior which deviates from the principle of legality, but by no means as illegal. The existence of this institute in the legal system represents a kind of support to the administration, bearing in mind that with the inaction of the administration at the request of the parties a fiction as if the administration did something is still being created, as if it passed a negative 
administrative act, or, less often, a positive one. However, this certainly does not achieve the compliance with principles by which a "good administration" should be governed. Especially if we keep in mind that the parties in the procedure were denied many rights by the silence of the administration, neither the administration actually decided on their requests nor the procedure was made more economical and efficient.

In resolving the observed legal-theoretical illogicalities and ambiguities that embody this institute, legal science and practice have shaped three models of legal regulation of the "silence" of the administration. The classification and its shaping was done according to the legal effect of the "silence" of the administration that various legal regulations give to this institute, (Dimitrijević, 2005). Thus, there are three models of "silence" of the administration: "silence" of the administration is legally viewed as if a negative administrative act has been adopted, the consequence of "silence" of the administration is the adoption of a positive administrative act, that is complying with the request and the fact of the existence of the "silence" of the administration is the reason for transferring the authority of decision-making upon the request onto another body. All three models have their advantages and disadvantages, which consequently creates the necessity of their combined presence. The mutual and synchronized effect of these models is even desirable, bearing in mind that the development of modern administration is directed at the support of the legal, efficient and democratic realization of the rights and interests of the parties, and not to legal justification and support of its inaction.

Our positive law, with the Law on General Administrative Procedure, (Law on General Administrative Procedure, 2016) provided the existence of an appeal due to the "silence" of the administration, that is the right of a party to an appeal if the administration did not issue a decision within the legally defined period. Such legal protection in our law has existed patterned to the model of French law, (Dimitrijević, 2005) since 1922 until today, with a break from 1930, with the adoption of the Law on General Administrative Procedure, (Law on General Administrative Procedure, 1930) which did not provide for the obligation of the administration to decide at the request of the parties within a certain deadline, until 1952 when the Law on Administrative Disputes, (Law on Administrative Disputes, 1952) was rendered, which filled this legal gap. A novelty in our legislation is the disabling of an appeal to that party if it is stipulated by a special law that the failure to issue a decision within the period specified by law is considered the adoption of the party's request, (Law on the General Administrative Procedure 2016). So, here we have the opposite situation, that is, we have submitted a request that is considered 
adopted under a special law, and we do not have a timely decision of the management. That is, a fiction of a positive decision was created here, regardless of the deadline prescribed for its adoption and its expiration. Accordingly, to the specified, the question arises as to the purpose of amending the ban on filing an appeal in this case, bearing in mind that the party has no legal interest in filing an appeal against the decision by which its request was adopted. The justification for the existence of such a norm is possibly in pointing out the possibility of prescribing the positive meaning of "silence" of the administration in special proceedings in the future, (Lončar, 2017).

The deadlines for issuing a decision are prescribed by the Law on General Administrative Procedure, which means rendering the decision and notifying the party about the decision which was rendered, and that is a period of 30 days for issuing a decision in the procedure when the administrative matter is decided by direct decision, or a period of 60 days for issuing a decision in the procedure when the administrative matter is not decided by direct decisionmaking, (Law on the General Administrative Procedure, 2016). In both cases, it is a procedure initiated at the request of a party or ex officio, and in the interest of the party. The law stipulates that if the body does not issue a decision within the legally prescribed period, an appeal may be filed after the expiration of that period, but no later than within one year from the expiration of that period. Therefore, this period of 1 year from the moment when the body was supposed to issue a decision to the party is preclusive, and the party loses the right to file an appeal due to the silence of the administration. In this case, a fiction was created that a negative decision was made on the party's request, and since such decisions do not become final, the party has only the opportunity to resubmit the request of the same content to the body that did not resolve the administrative matter within the legal deadline, (Lončar, 2017).

The problem of administrative inactivity, ubiquitous in the world, is solved in comparative law in different ways. The prevailing approach is to prescribe deadlines for making a decision with the fiction of a negative decision, while allowing the possibility of fiction of the adopting decision as an exception under special laws, (Law on the General Administrative Procedure, 2016) (in addition to our country, this approach has been accepted by France, Italy, Slovenia, Croatia...), (Kovač, 2011). In addition to the fiction of a negative act, certain countries have added a parallel takeover (e.g. Austria or Slovenia) or mediation through an ombudsman (e.g. Sweden, the United Kingdom, the Netherlands), while in other countries there is a fiction of a positive administrative act based on general regulation or special administrative regulations, (Kovač, 2011). 


\section{Specificity of the institute of "Silence" of the administration in the administrative procedure conducted before the Real Estate Registry and Cable Duct Cadaster}

The role of administration in the life of each individual, as well as in the overall functioning of society and the state is extremely important. Hence the great effort to make it more efficient and more transparent, while respecting the principles of the rule of law, equality, democracy and legality. Accelerated growth and development of our economy, especially the branch dealing with construction, then the creation of such an environment that will favor the inflow of foreign investments and investments necessarily requires up-to-date, accurate and transparent public records on real estate and cable ducts and rights to them. Real estate registry and cable duct cadaster data are the starting point for exercising various rights and obligations and must be reliable. Therefore, both for the sake of the individual and for the sake of the public interest, the real estate registry and cable duct cadaster must meet all the requirements set by the state and society.

One of those requirements is, of course, solving the cases within the deadline prescribed by law, whether they are cases that are conducted ex officio or those submitted at the request of a party. In both cases, it is necessary to solve the requests and make a decision based on the law within the deadline set for that. However, having in mind the specifics of the administrative procedure before the real estate registry and cable duct cadaster, as well as the existence of the principles with which the cadaster is kept, the institute of silence of administration must in certain situations be viewed differently from its application in proceedings before other administrative bodies. This is, after all, one of the reasons for passing the Law on the procedure of registration in the real estate registry and cable duct cadaster, (Law on the Procedure of Registration in the Real Estate and Cable Duct Cadaster, 2018) all with the aim of simplifying the procedure before the cadaster as an administrative body, shortening deadlines, increasing expediency and creating an up-to-date database on real estate and rights over them. Also, one of the reasons for rendering this Law is the obligation of adjusting the rules of special procedures with the Law on General Administrative Procedure, so as for the level of protection of citizens' rights in the procedure before the real estate registry not to derogate from what is guaranteed by the Law on General Administrative Procedure.

With the adoption of this Law, as well as its previous amendments and additions, then the implementation of reforms in the organization of the Republican Geodesy Bureau, the work of the real estate registry and cable duct cadaster has become completely transparent and accessible to the public, 
(Law on the Procedure of Registration in the Real Estate and Cable Duct Cadaster, 2018), the obligation has been prescribed for the obligor to deliver within the designated deadline from the certification, solemnization or judgement being made absolute which was brought to the real estate registry and cable duct cadaster, (Law on the Procedure of Registration in the Real Estate and Cable Duct Cadaster, 2018), to submit a document suitable for registration in order to implement the change in the records, shorter deadlines for decision making than those prescribed by the Law on General Administrative Procedure are envisaged, (Law on the Procedure of Registration in the Real Estate and Cable Duct Cadaster, 2018) the method of delivery of the decision is defined, as well as the possibility of posting on the notice board on the web presentation of the Republican Geodesy Bureau, (Law on the Procedure of Registration in the Real Estate and Cable Duct Cadaster, 2018) which has significantly influenced the more efficient and faster solving of requests, increasing the timeliness and quality of data, as well as their availability to the public.

Through the e-counter, the Bureau provided connection with all users, and the parties were given the opportunity to submit complaints, other legal remedies as well as the evidence they enclose with them in the form of a paper document. Therefore, the regulation of the provisions related to the electronic functioning of the cadaster did not affect the rights of the parties to, if they are not professional users of e-counter, submit legal remedies to this body in paper form, which fully protects their rights.

In addition to respecting the already established principles of administrative procedure, (Law on the General Administrative Procedure, 2016) the Law on the Procedure of Registration in the real estate registry and cable duct cadaster prescribes the principles that guide the real estate registry in its work, (Law on the Procedure of Registration in the Real Estate and Cable Duct Cadaster, 2018). These principles are: the principle of registration, the principle of officialdom, the principle of publicity, the principle of trust, the principle of priority, the principle of legality and the principle of determinateness. Their standardization is certainly necessary having in mind that the procedure conducted before the real estate registry, as well as the administrative matter itself, are specific and require more precise determination, both from the perspective of substantive and procedural law. Without diminishing the importance of other principles, for the purposes of this paper, it is necessary to clarify the principle of priority as well as the order in acting on the submitted requests. Namely, the principle of priority implies that registration in the real estate registry and cable duct cadaster and determining the order of priority of rights in relation to a specific real estate, that is cable duct is performed according to the chronological 
order of receipt of documents submitted for registration ex officio, that is the receipt of requests for registration, unless otherwise determined, (Law on the Procedure of Registration in the Real Estate and Cable Duct Cadaster, 2018). From this formulation of the principle, we notice that a concrete real estate, consequently and legally, and notices, which are again related to a specific and a certain real estate, represent an administrative matter in relation to which an administrative act is decided and passed. Thus, the request before the real estate registry and cable duct cadaster must always refer to a certain real estate or cable duct, whether they are registered or pre-registered in the real estate registry and cable duct cadaster or have yet to be registered or pre-recorded at the same time as the decision on adoption of the submitted request.

Also, in connection with a specific real estate, it is possible to submit more documents for registration, that is to submit more requests for registration. The same applies when it comes to possessing the same share in a real estate. The rule is that the procedure is always carried out first after the delivery that was made first, that is after the request that was received first, (Law on the Procedure of Registration in the Real Estate and Cable Duct Cadaster, 2018). The existence of this, as well as many other principles on which the work of the real estate registry and cable duct cadaster is based, is not a novelty in our law, it has been taken over from land registry legislation upon establishing the real estate registry and transferring the jurisdiction over keeping the records on proprietary and legal rights evidence from land registry courts to real estate registry, (Cvetić, 2009). Upon the decision made in the procedure on the previously submitted document, that is request, has been made absolute, the later submitted documents, that is requests, in the order of receipt, shall be taken into the procedure, (Law on the Procedure of Registration in the Real Estate and Cable Duct Cadaster, 2018). The order of decision-making cannot be violated by a special law. An exception to this rule is prescribed regarding the priority procedure for registration made on the basis of regulations governing expropriation, as well as the entry of a note on the decision on execution made on the basis of a mortgage agreement, or a lien statement, if previously a registration of the mortgage on the basis of those contracts, that is lien statement has been made in the real estate registry, unless there are unresolved cases of registration according to decisions being made absolute and according to the requests that preceded the registration of that mortgage. Therefore, the deviation is absolute in relation to the implementation of decisions made in the expropriation procedure, that is the registration of such decisions in the real estate registry and cable duct cadaster is carried out regardless of whether there are previous requests or 
previously submitted other documents ex officio for registration. Regarding the registration of the decision on enforcement, two conditions must be met for out-of-order dealings. The first is that the claim is already registered in the encumbrances evidence of the real estate registry and cable duct cadaster, and if not, that entry is not preceded by solving cases filed for registration of court decisions and those requests that precede the registration of that lien.

The existence of this principle is necessary in order to fully protect the rights and interests of all parties and participants in the procedure before the real estate registry and cable duct cadaster, bearing in mind that the assumed attitude is that the priority in solving has the request submitted first for the same real estate or the share in it, thereupon after the decision has been made absolute, the next request can be solved, and so on, democratic, fair, verifiable and absolutely not abusive in this information age.

Accordingly, as determined by law in which situations the real estate registry and cable duct cadaster can proceed to solve the following request, the complaint due to the "silence" of the administration in those proceedings preceded by the final decision of some or some other submitted requests, is at least untimely. Such "silence" of the administration can in no way be considered legally inadmissible. In fact, the real estate registry and cable duct cadaster is prevented by law from making decisions in such proceedings. Also, one of the reasons for rendering this Law is the obligation of adjusting the rules of special procedures with the Law on General Administrative Procedure, so as for the level of protection of citizens' rights in the procedure before the real estate registry not to derogate from what is guaranteed by the Law on General Administrative Procedure. For those requests and documents, the deadlines prescribed by the law for resolving have not started to run, that is the procedural preconditions for filing a complaint due to the "silence" of the administration have not been met, so it is completely unnecessary to submit it, while in practice their submission is frequent. That is, neither the case is in the phase when it can be resolved, nor can the fiction of a negative decision be created. When we take into account that the data from the records on real estate registry and cable duct cadaster and rights to them, with respect to the protection of personal data, as well as data on submitted requests related to a specific real estate and cable ducts, are completely public, it is unclear why the parties and their representatives generally use this legal remedy when they can see from public insight how many requests have been submitted and which is theirs according to the order of submission. It is more expedient, alongside proving the legal interest, to influence the possible decision in the preceding case, and in relation to the one the deadlines for decision-making 
can be applied, and not to appeal against the "silence" of the administration with an outcome that is known in advance, and which cannot be positive in any way. This does not do anything good, not for the party, let alone for the managing authority. It is only that the work of the institution is being slowed down, considering that such an appeal initiates in the procedural legal sense the engagement of civil servants and procedural correspondence between the second and first instance administrative body, that is the procedure legally regulated by the Law on General Administrative Procedure is initiated, (Law on the General Administrative Procedure, 2016). Namely, the complaint due to the "silence" of the administration is submitted to the second instance body, (Law on the General Administrative Procedure, 2016) which upon receipt of the complaint requests the first instance body to inform it of the reasons for not issuing the decision within the deadline, so the first instance body starts working on the case in order to submit a response to the second instance body in which it describes the factual state of inability of dealing with the case, so that the second instance body, on the basis of such a response of the first instance body, would decide on the complaint, that is make a decision to dismiss the complaint due to the "silence" of the administration as being premature. In practice, it often happens that a party submits a complaint to the first instance body, which further slows down the work following the complaint because the first instance body should first submit the complaint to the second instance body, so that everything would be done in procedural and legal sense as it has been previously stipulated. All this significantly complicates the work of the real estate registry, which requires greater energy in handling and the always existing imperative requirement for efficiency. Premature, and often flat-rate, complaints about the "silence" of the administration only seem to damage the work of the real estate registry and cable duct cadaster and jeopardize the realization of the rights and interests of all other parties who put their demands before the cadaster, whose claims are consequently solved ever more slowly.

\section{Conclusion}

The real estate registry and cable duct cadaster, as an administrative body, bases its work on all principles of administrative procedure, prescribing the principles of public records on real estate and rights to them that are specific for this special administrative procedure and administrative matter on which this administrative body decides in accordance with its own competencies. By standardizing the procedural and legal rules of the administrative procedure conducted before the real estate registry and cable duct cadaster, 
a faster, more efficient, up-to-date solving of submitted requests was significantly influenced, and conditions were created for real estate registry and cable duct cadaster records, by transferring the obligation to submit certified, solemnized and final decisions for registration from the parties to the obligors of delivery: notaries, public executors, other administrative bodies and courts, becomes complete and accurate. The goals set by the reform in the real estate registry and cable duct cadaster and the effects of the application of the special law are reflected in greater trust of citizens and the public in the records of the real estate registry and cable duct cadaster, raising the responsibility of civil servants in the sense of more efficient administration, as well as meeting all other requirements set before an administration that should function as a "good administration".

The specificity of the procedure conducted before the real estate registry and cable duct cadaster is reflected in the fact that it is possible to submit several requests for a specific real estate or cable duct, which one after another represent separate cases for which it is necessary to conduct individual administrative procedures in compliance with all prescribed deadlines for each and every (deadline for drafting the decision, notification on the decision, delivery rules, deadline for making the decision absolute...). Therefore, each subsequent request is waiting for its turn, that is, compliance with all deadlines prescribed for resolving the previous request, and only after the finality of the previous one, one can start solving the subsequent request.

Consequently, an appeal due to the "silence" of the administration filed by the parties in cases that are not procedurally and legally due for being processed, cannot produce a positive legal effect for the party. It cannot "bear fruit", until the previously submitted request is finally solved, when the deadlines for making a decision on the next request begin to run, and if the body does not act within the deadline for making a decision in that request until the dilatory deadlines expire, which concern the legal obligation of the administrative body to make a first instance decision, when the fiction of passing a negative administrative act is created. Such complaints due to the "silence" of the administration are not expedient and their consequence is slowing down the work of the cadaster, additional burden on both the first and second instance bodies to make decisions concerning the submitted request, which do not resolve the request on the merits. The reason for using this legal remedy is particularly unclear, given that the data of the real estate registry and cable duct cadaster are available to the public, while respecting the protection of personal data, and when information on specific real estate and submitted requests for registration can be obtained at any time. 


\section{Torbica Milica}

Doktor pravnih nauka, Republički geodetski zavod, Republika Srbija

\section{"ĆUTANJE UPRAVE" U UPRAVNOM POSTUPKU KOJI SE VODI PRED KATASTROM NEPOKRETNOSTI I VODOVA}

REZIME: "Ćutanje uprave" predstavlja sredstvo redovne pravne zaštite stranaka u upravnom postupku, bilo da se radi o postupku pokrenutom od strane zainteresovanih stranaka ili po službenoj dužnosti. U oba slučaja neaktivnost organa uprave za sobom povlači brojne posledice. Stranke u upravnom postupku, zbog dugog trajanja postupaka ili zbog nedonošenja odluka u zakonskim rokovima od strane uprave, trpe značajnu štetu. Katastar nepokretnosti i vodova predstavlja javnu knjigu koja sadrži podatke o nepokretnostima i pravima na njima koji su neophodni za ostvarivanje brojnih drugih prava pred ostalim državnim organima uprave i pravosuđa. Podaci katastra nepokretnosti i vodova predstavljaju polaznu osnovu prilikom ostvarivanja prava kod poslovnih banaka i u privredi uopšte. Stoga je neophodno da podaci katastra budu ažurni, što podrazumeva i aktivno i $\mathrm{u}$ roku sprovođenje isprava za upis u katastar, bilo da se na osnovu dostavljenih isprava za upis u katastar usvaja ili pak donosi negativan upravni akt. Međutim, u praksi često nema mesta primeni ovog instituta zaštite prava stranaka imajući u vidu da nepostupanje u upravnom postupku koji se vodi pred katastrom nepokretnosti i vodova nije uvek prouzrokovano nepoštovanjem rokova od strane ovog organa uprave. Naime, upravni postupak koji se vodi pred katastrom nepokretnosti ima svoje specifičnosti zbog kojih ovaj institut upravnog prava zaslužuje veću pažnju. Postojanje načela prvenstva, odnosno obaveze postupanja po zahtevima po redosledu njihovog prijema u katastru nepokretnosti i vodova, upućuje na drugačije gledište u pogledu postupanja organa uprave i donošenja odluke po zahtevima stranaka ili po službenoj dužnosti u rokovima propisanim zakonom.

Ključne reči: ćutanje uprave, katastar, načelo prvenstva 


\section{References}

1. Cvetić, R. (2009). Načela katastra nepokretnosti [Principles of Cadastre]. Zbornik radova Pravnog fakulteta u Novom Sadu, 43 (1), pp. 107-134

2. Dimitrijević, P. (2005). Odgovornost uprave za nečinjenje [Administration responsibility for inaction]. Istočno Sarajevo: Pravni fakultet

3. European Charter of Fudamental Rights, (2007/C303/01)

4. Kovač, P. (2011). Ćutanje uprave između zaštite prava stranaka i javnog interesa [Administrative silence between protection of rights of parties and public interest]. Pravni život, 60 (10), pp. 279-289

5. Lončar, Z. (2016). Posebni upravni postupci [Special administrative procedures]. Zbornik radova Pravnog fakulteta u Novom Sadu. 50 (4), pp. 1231-1248. DOI: 10.5937/zrpfns50-13080

6. Lončar, Z. (2017). Pravna sredstva u novom Zakonu o opštem upravnom postupku [Legal Remedies in the New Law on General Administrative Procedure]. Zbornik radova Pravnog fakulteta u Novom Sadu. 51 (4), pp. 1505-1523. DOI: 10.5937/zrpfns51-16415

7. Milkov, D. (1998). Upravno pravo: III kontrola uprave [Administration low III administration control] . Novi Sad: Pravni fakultet

8. Tomić, Z. (2013). Ćutanje uprave u Srbiji [Silence of administration in Serbia]. In: Radović, M. (ed.), Usklađivanje poslovnog prava Srbije sa pravom Evropske unije [Harmonization of the bussines Law of the Republic of Serbia and the Law of the European Union] (pp. 221-239). Beograd: Pravni fakultet, Centar za izdavaštvo i informisanje

9. Zakon o opštem upravnom postupku [Law on the General Administrative Procedure]. Službeni glasnik RS, no.18/16, 95/18 - authentic interpretation

10. Zakon o opštem upravnom postupku [Law on the General Administrative Procedure]. Službene novine, no. 271/30

11. Zakon o postupku upisa u katastar nepokretnosti i vodova [Law on the Procedure of Registration in the Real Estate and Cable Duct Cadaster]. Službeni glasnik RS, no. 41/18, 95/18,31/19 and 15/20

12. Zakon o upravnim sporovima [Law on the Judical Rewiev of Administrative]. Službeni list FNRJ, no. 23/52 